\section{Experimental modeling of the interaction of fluorine-containing granite melt and calcite.}

\section{YANA ALFERYEVA AND ANNA NOVIKOVA}

Lomonosov Moscow State University

Presenting Author: yanaalf@ya.ru

In our series of experiments, the contact interaction of fluorine-containing granite melt and calcite is simulated at $750^{\circ}$ $\mathrm{C}, 100 \mathrm{MPa}$ and a water content of $10 \mathrm{wt}$. \%. The initial composition of the granite melt in terms of the content of $\mathrm{Si}, \mathrm{Al}$, $\mathrm{F}$ and alkalis corresponds to the ongonites of the central facies of the Ary-Bulak massif (Eastern Transbaikalia, Russia): $\mathrm{SiO}_{2}$ $72,6, \mathrm{Al}_{2} \mathrm{O}_{3}-17,0, \mathrm{Na}_{2} \mathrm{O}-3,9, \mathrm{~K}_{2} \mathrm{O}-4,5, \mathrm{Li}_{2} \mathrm{O}-0,1, \mathrm{~F}-1,8$ wt.\%).

In the obtained experimental samples, there is a wellpronounced change in the composition in both the carbonate and silicate parts. At the contact of ongonite melt and carbonate, a zonal structure is noted. A zone is formed at the border, mainly composed of anorthite. A zone composed of silicate melt and alkaline feldspar is developed along the contact in the silicate part of the sample. When moving away from the contact, the feldspar disappears. The carbonate part consists of calcite, quartz, wollastonite, and cuspidine.

The figure shows the results of measurements of the sample composition over an area from 100 to $500 \mu \mathrm{m}^{2}$ at different distances from the contact. The carbonate part of the sample over the entire measurement area contains significant amounts of silica (up to $30 \mathrm{wt} \%$ ) and fluorine (up to $8 \mathrm{wt} \%$ ). When approaching the contact, the amount of silica increases, calcium decreases, and the fluorine content has a maximum at a distance of about $1 \mathrm{~mm}$ from the contact. A large loss of fluorine is noted in the silicate melt.

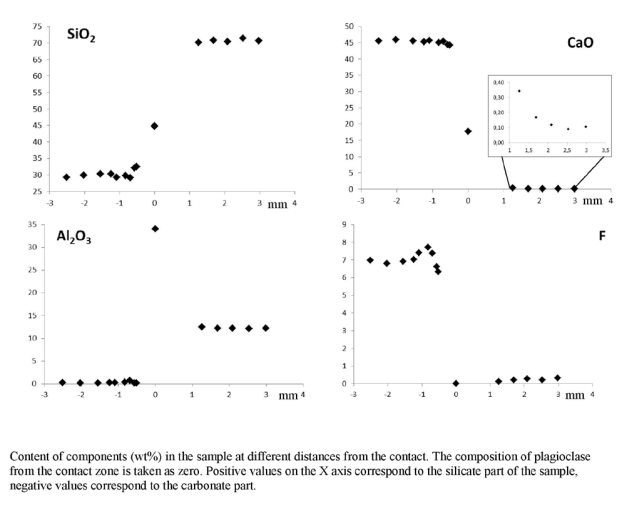

